\title{
The Lyrical Subversions of Socialist Realism in Đặng Nhật Minh’s New Wave Cinema
}

Dana Healy

Vietnam has long occupied a prominent space within the Cold War discourse, with the Vietnam War providing a particularly potent symbol of the ruptured world. The bipolar mindset that dominated the Cold War era has done much to obscure the complicated dimensions of the conflict on both sides of the Iron Curtain. At its extreme manifestation, it reduced this complex event to a crude ideologically-driven caricature where heroes and villains were neatly classified and respectively lauded or ostracized. Yet the longer we scrutinize the war's causes, analyze its results, and debate its consequences, the more complex and elusive it appears. The simplicity behind the "us versus them" rhetoric becomes blurred and contested with each new book, poem, film, memoir, archival document or scholarly study. But where conflicts are divisive, human suffering is unifying. Stripping away the hostile rhetoric of political campaigns, military strategies, and publicity crusades reveals a much simpler story of human strife, which transcends physical and ideological borders and allows the former adversaries to realize that their fates have had more in common than the acrimonious political vocabulary suggests.

The ideological ceasefire that marked the end of the Cold War unleashed a process of reorientation of Cold War studies, bringing the bipolar visions into dialogue. The debates on Vietnam and the Vietnam War have benefited from this process of global convergence that helped to draw attention to the Vietnamese perspective, egregiously neglected in Western scholarship. The Hollywood Vietnam War genre, through its Orientalist subjugation of the Vietnamese "Others," has largely excluded the Vietnamese from the great American tragedy, deeming them invisible, faceless and mute, demons without identity. The (North) Vietnamese, at the same time, concealed their own suffering from the outside world under the 
veil of the triumphant rhetoric of glorified national salvation. The shattering of these myths proved to be a precarious process, whose progress seems to be in jeopardy again as the Cold War rhetoric regains currency on the political world stage of today.

This chapter looks at the career and work of a prominent Vietnamese film director, Đặng Nhật Minh. Film, as indeed other creative expressions, has been utilized as a mighty weapon on both sides of the ideological battleground of the Cold War. Subsequently, it has proved to be an equally powerful instrument in the process of debunking of the propaganda and amending our understanding of the Cold War dynamics. The trajectory of Đặng Nhật Minh's work challenges the story of communist filmmaking as a servant to revolution, with little aesthetic ambition beyond its didactic and propagandist duty. Đặng Nhật Minh's films resist such one-dimensional categorization. Few Vietnamese artists have been able to forge an illustrious career applauded by the regime while at the same time becoming palatable to highly critical international (Western) and Vietnamese diaspora audiences (both traditionally fiercely dismissive of socialist art); similarly, not many of them have acted as advocates and simultaneous indicters of the regime. Given the tensions between the official communist collective history and individualized private histories of his film characters, how did a celebrated national filmmaker manage to produce films that offer a harsh critique of the communist regime yet remain lauded by the same regime? How does he reconcile highly individualized description of private fates in his films with the demands of cohesive collectivism advocated by the communist party's style $d u$ jour, socialist realism? How did he align his lyrical style with the stern unsentimental mould prescribed by socialist realism?

By taking a closer look at the film When the Tenth Month Comes, this chapter explores the ways in which Đặng Nhật Minh the artist and Đặng Nhật Minh Fthe revolutionary, patriot and communist party member, are reconciled in his films. 
When the Tenth Month Comes was made and released before the political and ideological thaw of the renovation era and reflects Minh's determination to uphold his creative autonomy and identity as an artist, despite the highly politicized cultural environment. Although his films were generally commended by the communist state, political efficacy, as prescribed by the regime, was never at the forefront of his creative endeavour. On the contrary, as this film shows, he frequently destabilizes the uniform, propagandist and laudatory aspects embedded within the tenets of socialist realism. His complex and ambiguous position as a regime supporter - yet, at the same time, as an independent and even subversive artist - shows that artistic production in Vietnam cannot be bracketed within neat and simplistic Cold War binaries.

Impassioned by Vietnam's long poetic tradition, Đặng Nhật Minh reaches for the lyrical as he navigates the vexing interaction of art and ideology. It is through the lyrical that Đặng Nhật Minh the artist reclaims his voice and asserts his autonomy. Lyricism in this sense is not just a genre or style but as David Der-wei Wang asserts in his discussion of Chinese lyricism, it is "a set of values or a 'structure of feeling' that registered a social episteme." It is a rich depository of ancient cultural values, traditions and ethics of the nation that reverberates in the hearts of the people to anchor their lives and configure their integrity.

In Đặng Nhật Minh’s films, lyricism becomes a productive force to destabilize the homogenous, stereotypical and propagandist visions of reality proffered by socialist realism; it empowers the director to personalize the country's history, validate private experiences and awaken emotions buried beneath the collective ethos of communism. His lyrical evocations of the eternal rhythms of life in the countryside, harmony with nature, the bond between the people and their land, the native village, the family ties - all reflect profound and everlasting 
values which make the political and ideological appear transient, trivial, and almost irrelevant.

The subversive character of Đặng Nhật Minh’s lyricism does not stem from adopting an openly dissenting stance against the regime but from his resurrection of the individual, from his affirmation of individual fates, experiences and emotions. It is not state or communist ideology which offers solutions to the tribulations of the people; rather it is the lyrical that harks back to ancient traditions and values, delving into the core of Vietnamese identity to provide solace in the face of hardship and suffering and serve as a poetic attestation to the resilience of the nation. The lyrical in Đặng Nhật Minh’s films is also instrumental in generating complex affects which contravene the monolithic function of political art, invoking melancholy, nostalgia, empathy and trauma.

Đặng Nhật Minh's lyrical subversions liberate his audiences, compelling them to assert their individuality and emerge themselves in the construction of the film's meaning. The lyrical helps the director mobilize a sense of loyalty, belonging and solidarity among the people, thus downplaying the role of politics and ideology in the nation's survival.

\section{Historical and Ideological Foundations of Vietnamese Cinema}

Beginning his filmmaking in the 1960s, Đặng Nhật Minh, who is still active today, has witnessed the dramatic evolution of Vietnamese cinema in the $20^{\text {th }}$ century, and his career reflects the myriad influences, upheavals, hierarchies, and allegiances that were instrumental in forging the shape of filmmaking in Vietnam.

Vietnamese cinema has always had a strong political orientation and was inextricably bound with state politics. Its birth is linked to the period of colonization and decolonization and the early stages of its existence are inseparable from the turbulent historical 
circumstances that mark the $20^{\text {th }}$ century in Vietnam. Following the establishment of a socialist state, Vietnamese Democratic Republic, in 1945, the communist authorities immediately took "a deep and abiding interest in cultural issues, both in a theoretical sense as well as in more substantive terms." ${ }^{2}$ They incorporated culture into the broader political agenda, creating and disseminating a new canon of culture that would contribute to the realization of their revolutionary goals. This period marks the beginning of a film industry in the North, which was thus born to serve the revolution. ${ }^{3}$ Decree 14/SL, signed by Ho Chi Minh on 15 March 1953, launched (North) Vietnamese film industry in a more official sense by establishing the Photography and Cinematography State Enterprise (Doanh nghiêp Quốc gia chiếu bóng và chụp ảnh). Even though film in Vietnam was still in its infancy, the communist leaders had recognized early on the need to detach this new medium from any bourgeois cultural tradition. Filmmakers were charged with making their art accessible to the masses - films centered on stock social themes and characters to convey a coherent ideological viewpoint and prop up the political regime.

The emerging Vietnamese film industry was also quickly embedded in the socialist state economy. As any other branch of industry, film production was incorporated into the centrally planned economy and was managed according to a five-year planning cycle. Film production and distribution-exhibition units received operating budgets allocated by the state. The centrally controlled system of cultural production enabled the state authorities to oversee all aspects of the filmmaking process: films were financed by the state, produced at the stateowned studios by state employed filmmakers, advertised and distributed by the state and scrutinized for their ideological correctness by state censors. The establishment of state film organizations, film periodicals and professional associations cemented total control over film production. 
Also important for the development of the local film industry and for Minh's own career, was Vietnam's gradual move into the orbit of the Soviet Bloc. 1949 saw the formation of Comecon (The Council for Mutual Economic Assistance), an international economic organization linking the Soviet Union with its East European allies, and later also developing countries in Asia, Africa, and Latin America that embarked on the path towards socialism. Comecon coordinated economic, trade, research and development activities of its member countries. Vietnamese officials were eager to align themselves with Comecon, gaining observer status for 1956-58 and becoming a full member in 1978. Consequently, Vietnamese cinema was gradually entwined into the framework of international transfers and exchanges shaping the culture of the socialist camp, creating a distinct and interconnected socialist culture. The Soviet cinematic internationalism functioned as a transnational enterprise to "influence, coordinate and cooperate with socialist filmmakers in their quest for a successful film aesthetic to portray the ideals of socialism in a way attractive to mass audiences." ${ }^{\prime 4}$ Practical aspects of this mission embraced a range of outreach activities, including film export and collaboration, artistic exchanges, regular forums, film festivals (above all, the Moscow Film Festival, a prominent platform to parade the best films that embodied socialist values) as well as a transnational system of financial and technical funding, co-productions and film distributions. These cultural affinities led Vietnamese cinema, in spite of its geographical distance, to forge a close connection to the cinematic traditions of the Socialist Bloc countries, including Bulgaria, Czechoslovakia, Romania, and Russia.

\section{Rethinking the Cold War}


The 1989 fall of the Berlin Wall, an event that visualized the dismantling of the Iron Curtain, marked a fundamental shift in global geopolitics and opened up new paths for a comprehensive reappraisal of the Cold War. Romero provides a succinct summary of the new trends:

Almost a quarter of a century later, historians are [...] expanding, dissecting, and complicating the very notion of a Cold War into a kaleidoscopic multiplication of prospects, contextualisations, methodological approaches, and meanings. We obviously situate the Cold War in longer-term perspectives of international and global transformations. We construct new hierarchies of significance - at times inspired by a rather more problematic presentism - from the long-term legacies that our current perspectives tend to prioritise. We decentre from a primarily Euro-Atlantic focus to the complex heterogeneity of the global South, and from a close frame on the superpowers' decision-makers to the agency of a variety of actors in Latin America, Asia or Africa. And we enlarge the field from the customary subjects of diplomacy, security and ideology onto a bracing assortment of trans-national and domestic, cultural and social, human rights and media, economic and intellectual history approaches. ${ }^{5}$

The greater integration of the countries of the Global South and the re-evaluation of the agency of these "peripheral" actors represents a vital shift, attesting to their agency rather than perceiving them as passive recipients of superpower politics. The understanding of how the peripheral others experienced and recount the history of the Cold War is central in liberating the debates from what Kwon labels as the falsity of uniformity. In The Other Cold War, he challenges the construct of a "unitary global cold war" which creates a false impression of a single or predominant Cold War experience. "Instead of one global cold war," he argues "the history of the global cold war consists of a multitude of locally specific historical realities and variant human experiences which conflict with the dominant as a 
single, encompassing geopolitical order." "With reference to South East Asia, scholars have also helped to underscore the agency of South East Asian countries, demonstrating that the conflict "was driven by regional historical imperatives as much as by global forces." Similarly, Hack and Wade argue that the "'South East Asian Cold War' was constituted by local forces drawing on outside actors for their own ideological and material purposes, more than by great powers seeking local allies and proxy theatres of conflict ...

Meanwhile, an expanding body of critical writings turns attention to the examination of culture (including visual culture) as one of the major battlegrounds of Cold War ideological conflict. Debates on the cultures in the bipolar world of the Cold War have been predominantly wrapped around issues of control and compliance with the respective political systems. As Scott-Smith and Segal explain: "two antagonistic power blocs defining their own interpretation of the world, contesting each other's utopian claims as dystopian designs, and manufacturing consent by a combination of soft power (coercion, intimidation, punishment) in the interest of collective security and identity." "Today's scholarship advances a more nuanced assessment demonstrating that notwithstanding conflicting ideological foundations, cultural expressions in both blocs often shared numerous commonalities (facilitated by various forms of collaborations and cross border exchanges). Even though both blocs declared their art to be intrinsically connected to their political systems, a degree of autonomy of cultural expression was often possible and many cultural works were in fact at odds with the clear-cut interpretations of capitalist or communist reality. ${ }^{10}$ While the use of propaganda in the East has been mapped extensively, in recent years the use of culture as propaganda in the West has also become a productive line of research. ${ }^{11}$

In shifting the focus away from the central superpowers, the post-Cold War scholarship has helped to accentuate the Vietnamese experience. While the high degree of ideological intrusions into pre-1986 cultural production in Vietnam is irrefutable and well- 
documented, scholars have increasingly cautioned against equating the entire cultural output to mere propaganda. Referring to Vietnamese cinema, Charlot, for example, argues that although in the early 1970s a number of films were simplistic and formulaic, later a commitment to questions of humanity, beauty, and moral character came to the fore. ${ }^{12}$ Others highlight the emergence of authentic Vietnamese aesthetics, a distinctive national character of Vietnamese cinema, derived from a combination of historical circumstances, pronounced ideological concerns and indigenous cultural tradition "with its vivid expression of the humanity, philosophy, and feelings of the Vietnamese." ${ }^{13}$

\section{Renovation and the Emancipation of Art from Politics}

Đặng Nhật Minh started making films at an opportune moment in Vietnamese history - a period of a slowly approaching ideological thaw marked by gradual political and cultural liberalization which eventually culminated in the launch of the đổi mói (renovation) reforms, which introduced widespread liberalization in economy, in 1986, and culture, in 1987.

Until Renovation, Vietnamese culture was dominated by socialist realism. The fundamental principles of politicized art were laid down in the 1943 pamphlet, Theses on Vietnamese Culture, penned by Trương Chinh, the Communist Party chief ideologue and a staunch follower of Marxism-Leninism. Socialist realism was elvated to become the only acceptable form of creativity. Art had to be realistic in form and socialist in content. Unembelished style guaranteed that the obligatory political messages would be easily understood by everyone and boastful language was to promote optimism and positive visions of the socialist future. As a result, cultural production became predictable, stereotypical and superficial. 
Within the considerably enlarged creative space facilitated by the Renovation, yet in the absence of total freedom, there was a stimulus for creativity to shatter the ideological strictures and offer an alternative to the monumental visions of socialist realism - a mission befitting Đặng Nhật Minh's inclination toward lyricism and emotional sensitivity.

Đặng Nhật Minh is a self-taught filmmaker. He originally trained as a translator from Russian, but an opportune vacancy at the Cinema Department brought him closer to the world of filmmaking. In his new position, he was tasked with translating dialogues of Russian films (which formed the majority of films screened in Vietnam in the 1960s) and assisted Soviet film experts in developing courses and tutorials for Vietnamese filmmakers. Here he became much closer to the world of fillmmaking, relishing the lectures, theoretical articles, and films assigned to the students. His love for cinema ignited, Minh pursued every opportunity to become a filmmaker, managing to supervise student graduation films and eventually creating his first works, which were documentaries. ${ }^{14}$ His first feature films, Chi Nhung (Miss Nhung, 1970) and Nhĩng ngôi sao biển (Starts on the Sea, 1973), were followed by his most famous work: Bao giơ cho đến tháng mươi (When the Tenth Month Comes, 1984), released before the Renovation reforms of 1986.

Although the communist authorities gradually turned Vietnam's artistic production into a eulogy to patriotism, revolutionary spirit, and national unity, Đặng Nhật Minh always searched for ways to imbue his films with emotions and empathy. With the end of war came a desire to recover the past from its ideological constraints but it was not until November 1987, when the communist authorities formulated their đổi mói cultural policies, abandoned socialist realism, and released artists from political control. The Renovation injected a fresh energy into Vietnamese culture and inspired a wave of literature and films that set out to rescue the "big" themes of war and revolution by peeling off the glossy collective ethos and 
rediscovering the private experiences obliterated within the earlier paradigms of socialist realism.

Minh's filmmaking was in many ways ahead of that of his peers. When the Tenth Month Comes, released in 1984, was one of the very first revisionist films contesting the official memories of war. By portraying the private process of mourning the dead soldier, Đặng Nhật Minh challenged the state's ennoblement of the war dead and reinstated the memory of the dead soldier to the private realm of his family kin. His later films remained focused on the portrayal of the fate of the individual, the most famous of them being Cô gái trên sông (The Girl on the River, 1987), Thuơng nho' dồng quê (Nostalgia for the Countryside, 1995), Mùa ổi (The Season of Guavas, 1999) and Đìng đốt (Don’t Burn, 2009).

Discussions on Vietnam's cultural production from the Renovation period frequently accentuate the centrality of its criticism of the communist regime. Whilst the wave of Renovation films is undoubtedly imbued with a strong critical potential, not all artists set out to be dissenting, certainly not always in a politically active fashion. Many, including Đặng Nhật Minh, were driven by their individual creative ambitions and desire for innovation and experiment. In many ways, the nature of Renovation cinema in Vietnam echoes the reformist new wave filmmaking that emerged throughout Eastern Europe in the 1960s in response to the broader political and cultural de-Stalinization process. The Czechoslovak new wave, for example, that blossomed following Alexander Dubcek's inauguration of "socialism with a human face" unleashed an unprecedented burst of cinematic creativity, as well as social critique. The Czech film scholar Lubica Učník explains that young filmmakers at that time "rejected as lies film schematism and the socialist realism of previous years to assert their right to authenticity, originality, and a meaningful artistic standpoint. The most important criteria became truthfulness, the desire to show human emotions, and conflicts rather than class-defined narratives and schematic sketches." 15 
Cultural production that grew out of Vietnamese Renovation, as Đặng Nhật Minh's example helps to illustrate, similarly desired to steer itself away from the restrictive formulae of socialist realism and explicit ideological grounding towards cinema of moral rather than political concerns; cinema of individual fates rather than collective crusades; cinema of sober critical reflection rather than boastful proclamation. Moreover, by refusing to voice explicit messages complementary to socialism and by directing works of art towards ambiguity and multiple meanings, Renovation art empowered its audiences by coercing them to think for themselves, cautioning against blind acceptance of authority. Scott's assessment of the more recent Romanian new wave also rings true for Vietnam's Renovation cinema:

There is almost no didacticism or point-making in these films, none of those characters are easily sorted into good guys or bad guys. Instead, there is an almost palpable impulse to tell the truth, to present choices, conflicts and accidents without exaggeration or omission. This is a form of realism, of course, but its motivation seems to be as much ethical as aesthetic, less a matter of verisimilitude than of honesty. ${ }^{16}$

Although the censors and audiences find ample political messages in Đặng Nhật Minh's Renovation films, a compelling argument can be made that his ambitions are creative rather than political, that he is pursuing his own personal sense of artistic truth and it is this creative impulse, and not a specifically political motivation, that provides the most fundamental impetus behind his films. ${ }^{17}$ What connected the various developments in the arts in Vietnam during Renovation was the rejection of the ideological servitude imposed by socialist realism. In its place, the filmmakers combined various stylistic and thematic methods with specifically Vietnamese historical, socio-political and cultural influences. Bradley, for example, notes that filmmakers employed 
a diverse repertoire of rich visual imagery that reached back to ritual forms of family and village life long suppressed by the state, the metaphorical and subversive uses of gender in traditional literary idioms, and the discursive strategies of anticolonial political discourse familiar to much of their intended audience. ${ }^{18}$

\section{Engaged Lyricism: Social Reality and Lyrical Sensibility in Đặng Nhật Minh’s Films}

There is much in Đặng Nhật Minh's work that defies the conventional expectations of the communist state's most celebrated film director working in historically and ideologically restraining circumstances. His films (and for that matter, his professional life) in many ways resist the predicament inherent in the binary of the pro versus against, official versus dissenting stance of artist in a communist regime. Whereas Western Cold War scholarship has been inclined to designate artistic production under socialism as belonging at either end of a spectrum of ideological compliance - either as apologist/propagandist or as dissenting/confrontational, in truth, as Đặng Nhật Minh's case helps to show, the range of approaches adopted by the majority of "working" artists was usually more nuanced and frequently involved a degree of compromise and strategizing. Within the supposedly monolithic artistic front, individual artists nevertheless adopted different tactics of compliance or resistance in coping with the demands of being an artist in a communist state.

Đặng Nhật Minh never allowed the testing historical and political milieu to incapacitate his imagination; if anything, he was spurred on by the challenge it presented. In his determination to maintain his artistic agency while still staying alert and relevant to the complicated reality around him, Đặng Nhật Minh frequently summoned the aesthetics of 
poetic realism, infusing his films with lyrical mode as a way to counteract the dispassionate conventions of socialist realism. In his work, lyricism becomes a productive tool he calls on in his attempt to reconcile the political/collective and the intimate/individual.

Most of Đặng Nhật Minh’s films are imbued with a kind of poetic ambience that rises above transient ideology and directs the spectators towards more profound and eternal values of humanity. This is not to say that the director shies away from engaging with the decisively un-poetic reality around him. Not only would it be unimaginable given the magnitude of historical events that provide a backdrop to his career, it would also mean disregarding his genuine patriotic feelings and empathy with his suffering nation. His lyricism is not a form of irrelevant romantic escape from the dramatic circumstances but a sensual meditation on reality, which enables him to incorporate into his films diverse voices and legitimize previously marginalized aspects of the past. Paradoxically, by softening the coarseness of ideology, by placing emphasis on imagery and emotions, by featuring contemplative scenes that compel people to mull over their actions, he crafts films that evoke a sense of commitment and solidarity with the nation in a more powerful way than could ever be achieved through plain political servility.

\section{Sources of Poetic Tradition}

Đặng Nhật Minh's distinct artistic language draws its inspiration from several sources. Much of his lyrical sensibility is directly rooted in Vietnam's long poetic tradition, both its oral as well as classical scholarly forms, and is heightened by the director's deep attachment to his homeland, its people and cultural tradition.

Fondness for poetry is an innate part of Vietnamese sensibilities. Poetic expression has dominated Vietnamese culture from ancient times and poetry always enjoyed high 
prestige. At the time when Vietnam was engulfed in the "epic" eras of war and social upheavals, Minh's incantation of the lyrical may seem anachronistic or inapt. Yet, as demonstrated by many scholars, in Vietnam, poetic discourse has long played a significant role in the larger process of historical change as it helped shape Vietnamese society through its moral, philosophical, and political guidance. As Chinese literary historian David Wang points out in reference to China, the concept of Chinese poetics "has always indicated an interaction between the self and the world and beyond" and artists in China often "invoke the lyrical as they came to ruminate on the stakes of selfhood vis-à-vis solidarity, pondering historical contingencies and poetic/artistic assertions and experimenting with forms that they believe best cast light on and responded to the time of crisis." ${ }^{19}$ Similarly in Vietnam, in turbulent times, poetry assumed a crucial role in "preserving and transmitting the national identity without which Vietnam couldn't have survived a thousand years under Chinese rule. ${ }^{20}$

In his contemplation on the relationship between history and poetry in Vietnam, Jamieson asserts that poetic discourse humanizes history, expands our moral imagination, and stimulates our capacity for empathy by sensitizing us to deeper levels of meaning. ${ }^{21}$ Equally important is the ability of poetic expression to imbue ambiguity, incorporate a multiplicity of voices and perspectives within a single text, which, even in the heyday of socialist realism, incited audiences to read between the lines and collaborate in the production of meaning. It is precisely through this multiplicity of perspectives and spectrum of possibilities of interpretation that Đặng Nhật Minh’s films become free from a fixed ideological meaning and achieve such emotional potency.

Another crucial influence that was instrumental in shaping Minh's artistic style comes from Soviet cinema. By the time he started making films, Vietnamese film industry was already imbued with the Soviet filmmaking tradition, which provided a powerful source of 
inspiration for Minh and his contemporaries. As Đặng Nhật Minh’s experience shows, most film cadres in Vietnam in the second half of the $20^{\text {th }}$ century, both artistic and managerial, were new recruits, with little skills and no formal education in film. Their training, or to use the political terminology, "the cultivation of cultural cadres," became an urgent task for the Vietnamese authorities, and in the absence of a domestic film school, the Vietnamese government dispatched in 1956 a first group of students to be trained in Moscow at the All-Soviet State Institute of Cinematography (VGIK). VGIK became an important training ground for filmmakers from developing countries, so much so that Ngô Phương Lan, Director of the Vietnam Cinema Department under the Ministry of Culture, Sports and Tourism, a VGIK alumni herself, refers to VGIK as the "cradle" of Vietnamese film and credits it with the subsequent sucesses of Vietnamese cinema. Nearly all filmmakers holding key positions in Vietnamese cinema had been educated at VGIK. In spite of its political allegiances, VGIK gradually became an important creative hub, "a relatively protected artistic sanctuary." ${ }^{22}$ It was a rare place in the Soviet Union where students could encounter Western cinema. As Näripea explains,

The institute of cinematography had put them into contact with Western cinema's history and its newest trends, both directly - through films that were shown as part of their coursework but whose screening was prohibited to the general public - and indirectly - through the works of their teachers who were among the best filmmakers of their times. ${ }^{23}$

It was a long held aspiration of Đặng Nhật Minh to study at VGIK. When his job as a translator brought him into the proximity of VGIK alumni, he soon began to yearn to join their ranks and gain a professional training at VGIK. Having been repeatedly rejected by the Vietnamese authorities, Đặng Nhật Minh wrote to VGIK with a request to join a distance learning course, only to be again disappointed that VGIK did not offer any distance learning 
programs. The head of the Institute was nevertheless so impressed by Đặng Nhật Minh's determination that he sent him study materials, which the aspiring director perused with passion. He remembers:

I devoured these textbooks as if I was a student preparing for exams. I learnt the meaning of shot size, mise en scene, Eisenstein's understanding of the concept of mise en cadre, I learnt how to organize each sequence, the role of actors, and most importantly, I learnt about the importance of montage. ${ }^{24}$

In spite of the physical distance from VGIK, Đặng Nhật Minh was in close proximity to VGIK's artistic stimulus. Soviet film experts were coming to Vietnam to run courses for local filmmakers and Vietnamese filmmakers trained at VGIK were returning home to impart their newly-acquired knowledge of film craft. Among the films that were particularly popular at the time were Mikhail Kalatozov's The Cranes are Flying (1957), Grigori Chukhrai's Ballad of a Soldier (1959), Sergei Bondarchuk's Fate of a Man (1959), as well as films by Mikhail Romm, Andrei Tarkovsky, Andrei Konchalovsky and others. The artistic influence of these Soviet filmmakers was crucial for the development of Minh's own style as an auteur. He was attuned to their delicate lyricism, which suited his own sensitivity rooted in the poetic tradition of his homeland. He could relate to their expressive style, intensity of emotions, and emphasis on the visual radiating through their stories of love, loss, and individual isolation. On another level, he also took notice of how they navigated complex socio-political circumstances, made do with limited financial and technological resources, and he also recognized the strategies necessary to balance the aesthetic with the political when working within a highly politicized cultural milieu.

A limited selection of "progressive" Western films also made it through the Iron Curtain, for example Italian Neorealism or French nouvelle vague and their various later 
reincarnations from other countries. The vibrations of these "new waves" from both the Eastern Bloc and the West, with their tendency to focus on everyday life, daily struggles of ordinary people, authentic environment and emotions, found their way into Đặng Nhật Minh's work and into Vietnamese cinema as a whole. These films with their realistic feel, portraying the tribulations of ordinary people struggling to make sense of their lives amidst economic hardship, social upheavals, and oppression resonated with the Vietnamese reality (and with the realist artistic tradition). Later in his career, especially during his stay in France, Đặng Nhật Minh had more opportunities to draw upon inspiration from the acclaimed films of French directors such as François Truffaut, Jean-Luc Godard, Alain Resnais, Éric Rohmer, Maurice Pialat, André Téchiné or other foreign filmmakers, including Roman Polanski, Miloš Forman, Akira Kurosawa, Yasujirō Ozu and Kenji Mizoguchi.

\section{Representing the War: When the Tenth Month Comes}

Đặng Nhật Minh's significance as a powerful artistic voice derives from his ability to craft intricate, sensual, and moving films which ruminate over major events that have shaped Vietnamese society in the twentieth century - the most poignant among them is the war and its painful legacy.

War is a major theme in Vietnamese cultural production of the $20^{\text {th }}$ century and as many scholars assert, its memories have become strategically important in the state's efforts to fashion a coherent narrative of the country's past, which served to legitimize the regime. Under the reign of socialist realism, the topic of war was reduced to an impersonal affair which substituted genuine human emotions with impassive ideological proclamations. As I have illustrated elsewhere, while many artists in Vietnam were willing to sacrifice their freedom of creativity during the war in order to fulfil their patriotic obligations, passive 
obedience and conformity was no longer aceptable to them once the war was over. ${ }^{25}$ As a result, many artists strove to reclaim their freedom and rescue the topic of war from its formulaic treatment. For example, in 1978, Nguyễn Minh Châu, an influential Vietnamese soldier-writer, took a brave decision to voice in the essay Viết về chiến tranh (Writing about War) his disillusionment with the treatment of the war in Vietnamese literature. Among the main weaknesses he highlights the presence of one-dimensional characters lacking veracity and psychological depths, a simplistic concept of a hero, a sanitized version of the war, and a dream-like reality riddled with discrepancies between official accounts of war as a historical event and the personal memories of the participants. ${ }^{26}$

In agreement with Nguyễn Minh Châu critique, Đặng Nhật Minh set out to liberate the topic of war from its ideological distortions. He embraced his lyrical sensibility to rescue this subject matter from the paradigms of collective triumph and explore it instead within the paradigms of loss and private trauma. His films do not take place on the battlefield and the tragedy of war is expressed rather through its suffocating omnipresence in people's lives, irrespective of whether his film takes place during wartime or in its aftermath. His anchoring of memory of the war lies in the rendition of "private wars." By turning to universal human concerns, such as love, family, sacrifice, forgiveness, and spirituality, and by sidestepping ideology, his films inevitably complicate and contest the state's simplified ideological construct of war.

The poetic qualities of Đặng Nhật Minh's films are further displayed in the description of romantic love, which helps to mitigate the austere reality. Poems, lyrical music, or songs are often incorporated into his films as additional stylistic tools, which (almost as an interactive commentary) frame his films, infuse them with a contemplative mood, or refer them back to the Vietnamese cultural traditions. 
Đặng Nhật Minh's lyricism is clearly on display in When the Tenth Month Comes, his most celebrated film to date, shot in black and white and released in 1984. In the history of Vietnamese film, few works match the significance of this critically acclaimed masterpiece with prestigious accolades to its name, including the highest Vietnamese film award Golden Lotus in 1985, special prize at the Asia-Pacific Film Festival in 1989, and a distinction at the International Hawaii Film Festival in $1985 .{ }^{27}$ This film also occupies a unique position in the Vietnamese film canon by being arguably the most internationally famous Vietnamese film.

The original script, which Đặng Nhật Minh wrote himself, was inspired by a chance encounter with a village funeral procession. As he recollects in his film diaries, he was struck by the powerful image of a lonely widow walking in the procession, mourning a husband who in fact died several years ago. The film tells the story of a young widow, Duyên, who, upon learning of her husband's death in the war in Cambodia, conceals this news from her ill father-in-law and her young son to shield them from pain. She enlists the help of a local teacher who composes letters that she passes off as coming from her husband at the front, maintaining a pretence that he is still alive. Her deception, although well-intentioned, becomes a source of major drama as it infringes on the complex commemoration practices of the war dead.

The film is constructed around the memory of a dead soldier, an issue which encapsulates in Vietnamese society a range of ideological, cultural, and emotional concerns. In communist Vietnam, the death of a soldier, one of the most potent symbols of war, is a predicament of major political manoeuvring, as it is so demonstrably the result of political action. As Malarney illustrates, the politicians in Vietnam integrated fallen soldiers into a pantheon of national heroes in order to legitimize the war losses and the regime itself. ${ }^{28} \mathrm{By}$ claiming the ownership of the soldier's memory and exploiting it as a vehicle for nationalism and communism, the authorities infringed on the private grief of the families of the dead, 
encroaching on their private mourning and the traditional funerary rites of passage into the other world, which lay the soul of the deceased to rest within the familial ancestral line.

Mourning and a fallen soldier are important tropes in Vietnamese war films, which assume, as Bradley points out, "a central place in the symbolic vocabulary of the revisionist films of the 1980s." ${ }^{29}$ In When the Tenth Month Comes, Đặng Nhật Minh constructs an intricate exploration of this theme, complicated further by the concealment of the death. While the official state commemorations glorify the death in combat, it is the private memory that reverts back to the paradigm of loss, suffering, pain, and sorrow - thus transcending the specific historical and geographical setting, ideological allegiances or even nationality, to give this film a universal validity that holds true for all wars.

The director's poetic aesthetics serves to unsettle dogmatic ideology and as Charlot notes, “it is this poetic sense which separates Đặng Nhật Minh’s films from conventional socialist realism. ${ }^{\prime 30}$ Whereas socialist realism demanded that the war death be portrayed within the officially enshrined political clichés of glorified sacrifice, Đặng Nhật Minh privileges the subjectivity of emotions over ideology. Like the best poets before him, he invites the audiences to recognize their own subjectivity and submerge themselves in his film, finding echoes of their own wars. This is not an easy task in a cultural tradition built on prescriptive Confucian and communist ethics, which command discipline, uniformity, and unquestionable loyalty. Where the official party line demanded explicit clarity, Minh brings to light complexity and ambiguity; where it called for firm didactic guidance, Minh instead gently goads the audiences to mull over orthodox views and think for themselves; and where it commanded a steadfast ideological imperatives, he puts forward a deeper morality and spirituality instead.

Lyricism in Đặng Nhật Minh’s films functions both as a remedial and subversive tool: his probing sensitivity amends, complements, contests, casts doubt, discredits - in short, 
complicates, the homogenous officially sanctioned account of war. His war is not an abstract war: he rescues the myriad of individual forms of grief, giving war loss an image that is tangible, palpable, and which resonates with the audiences, many of whom would have been through their own process of mourning. Instead of restaging grandiose victories on the battlefields or hiding behind conceited political slogans, his films turn focus on the intimate, on domesticity, on unremarkable daily routines and age-old traditions to communicate the devastating impact of war on human lives.

Đặng Nhật Minh's type of lyricism is imbued with a profound sense of homeland and rootedness, yet his patriotism stands above ideology. This affection for the native land is visualized in When the Tenth Month Comes through a poetic rendering of the Vietnamese countryside and is further reinforced through the portrayal of the deep ties within a Vietnamese family and village community. Small vignettes of the traditional rural life and emblematic images of natural landscape convey a peaceful ambience, which instils a sense of harmony, survival, and hope.

The tormenting ordeals that plague his characters are contrasted by the unassuming calmness of the natural landscape or the monotonous cycle of life, heightening the emotional impact of his films. The clichéd pastoral imagery of rice fields, rivers, trees, or village alleys reproduces a sense of stability in otherwise uncertain times of crisis facing the protagonists of his films. This seemingly "boring" visual monotony becomes aspirational and dreamlike for the characters whose lives have been irrevocably upset. The trauma of war, death, betrayal or loss of home/homeland is invoked poignantly, not through screams, weeping, or animated confrontations but through the forfeiture of the normality of life.

The recurring landscape shots invoke a sense of nostalgic tranquillity and frame deceptive moments of respite, unbound from time, history and ideology. Yet these 
expressionistic poetic interludes are soon exposed as false when the underlining narrative of trauma invades the mise-en-scène provided by the landscape images. The ominous cues of the looming tragedy - the recurrent close-ups of Duyên's eyes filled with pain and panic, the sudden sound of a toy gun, the figure of a soldier in the distance or a close-up of an ancestral altar - reintroduce the seemingly absent historical circumstances, imprinting a sorrowful melancholy on the idyllic pastoral images.

Film landscape in Minh's film is not just an object of the visual gaze, but serves as an additional semantic source extending the narrative space. In her discussion of Italian melodramas of the 1990s, Galt ruminates over the politics of landscape, emphasizing the capability of cinematic landscape to code spatial, political and psychological transformation. Rejecting the role of a filmic landscape as simply aesthetically pleasing and separate from the narrative, she argues for an ideological complexity of the spectacle where images are not just heritage shots or static moments of spectacular freezing. ${ }^{31}$

The use of filmic landscape enables Minh to cut through the major issues of space, time, and identity to retrieve the film's central trope of mourning from its political misappropriation. His landscape images become the depositories of a natural authentic way of life untainted by ideology. While the landscape in Minh's film still preserves the contours and parameters of the national space with its reverberations of history, tradition, rituals, and spirituality, it is simultaneously a deeply private intimate space. The spirituality encapsulated in his landscape, filled with shrines, altars and spirits, privileges intimacy and hints at the redemptive possibility offered by the landscape. The political events as well as the state's authority fade into insignificance in the presence of the eternal natural cycle of life. The fact that the film evolves against the backdrop of the Vietnam War in Cambodia, is, on the surface, almost not noticed. For example, the opening sequence, underpinned by highly 
lyrical musical score, shows Duyên returning back to her home village and there is nothing that immediately betrays the fact that she has just learned of her husband's death.

\section{[INSERT HEALY-FIGURE 1 HERE] and [INSERT HEALY-FIGURE 2 HERE]}

In the absence of any plot to speak of, the film's dramatic action derives almost entirely from the portrayal of Duyên's overwhelming emotional ordeal. Đặng Nhật Minh turns a seemingly innocent and well-intentioned lie into an inspired rumination on the profound issues at the heart of Vietnamese identity. Through recurring close-up shots of Duyên's face, the director captures a sense of her escalating panic as the gravity of her decision to keep her husband's death a secret dawns on her. Each seemingly innocent question about her husband pulls her deeper into a web of lies, resulting in a suffocating guilt. Her secret isolates Duyên from others and the director accentuates her loneliness by frequently positioning her at the edge of the frame, in the corner of the room, out of sight of others, through her lack of eye contact or distant look on her face. The more the film displays the importance of family and community ties, the more of an outcast is Duyên becoming. Her intense anguish stems not only from her personal loss, but more crucially from denying her husband the mandatory process of worship, entrapping him as a restless wandering spirit. The family and village gatherings, especially the death anniversary feast for Duyen's mother-inlaw, reflect the importance of ancestor worship.

Duyên's emotional strain reaches its climax during the scene of the village performance of chè (traditional opera), which is among the most compelling moments in the film. Duyên's stage role resonates with her own fate: a wife weeping over her husband who was sent to war. The traditional chè genre often dramatizes ancient stories of war heroism canonized in history, which are presented to the audiences through highly stylized form of acting, staging, and movement. It evokes Vietnam's protracted history of war and aligns 
Duyên with countless women in Vietnam's history who faced the same tragedy, turning her character into an archetype of a bereaved wife who lost her husband to war. Her act also echoes a famous eighteenth century Vietnamese poem, Chinh phụ ngâm (The Lament of a Warrior's Wife) in which a Confucian wife, left behind when her husband went off to war, laments her fate. Through these reverberations with an old and well-known poem, Minh directs us again to the historical tradition rather than to the political presence. As we listen to Duyên's declamations and watch her stylized gestures, the camera guides us to a series of small signs that signal her impending psychological collapse. For example, as she raises the edge of her costume to her eyes in a stylized dramatic gesture, which traditionally symbolizes weeping, we sense that she covers her eyes for a fraction of a moment longer than the scene demands. Does she stay turned away from the audiences longer than necessary to conceal her own agony? Minh gradates the tension leading up to her breakdown when she rushes off the stage, unable to bear the pain any more. Her abrupt departure destabilizes the diegetic performance: her private grief having infringed upon the choreographed stage act, awakening the film audiences to her individuality and humanity - she is no longer a stereotyped character but a real widow consumed by grief. Duyên's public display of sorrow unsettles the fixed narrative of war sacrifice, casting doubt on its veracity. By exposing her own pain, she metaphorically retrieves the memory of her fallen husband, and the cheo performance, repeated thousands of times before, suddenly acquires a different meaning - rather than reinforcing the state's narrative of glorified war, it appears flawed and manipulated.

\section{Realm of the Spirits and the War Dead}

Another important method of recovering the memory of the dead soldier is to link it to the familial space back home. In When the Tenth Month Comes, this return is facilitated through 
the figures of ghosts and through the construction of the space in between real life and the afterlife. The spirits serve in the film as a metaphor for the omnipresence of an unresolved past that still haunts the present. Upon its release, the intense spirituality pervading Minh's film - especially the presence of the ghosts - alarmed the authorities as elements at odds with the atheist ethos of communism. Yet Vietnamese culture and religious tradition place the utmost importance on the spirits of the deceased and the world of the living and the dead is intimately bound together. In his anthropological study of war death and memory, Heonik Kwon explains that these ghosts of the war play an important part in post-war Vietnamese historical narrative and imagination as lingering reminders of historical injustice, social inequality, and Cold War division. ${ }^{32}$ More importantly, as he also notes, the spirits suffer from historical amnesia: they no longer recollect the ideologies, violence, enemies, heroes, cowards, combatants or civilians. This ideological amnesia is significant as it locates the spirits among their family kin rather than in the communist family-state and thus polemicizes yet again the state's account of war.

The authoritative role of the ghosts as moral guardians gives them power over the living that diminishes the state's effort to control commemorative practices and it is this supremacy of the spirits that gives the film its dissenting character. Whereas the state's commemorative practices privilege selfless heroes and altruistic martyrs, the private worship by the families and communities is unconditional and non-discriminatory and Đặng Nhật Minh generates much of his film's powerful emotions from reflecting on this deep bond and filial piety.

\section{[INSERT HEALY-FIGURE 3 HERE]}

Đặng Nhật Minh's penchant for the lyrical comes to the fore in his rendering of the spirits. The interconnectedness of the living and the dead is alluded to in the film through the seamless transitions between the two realms. Minh avoids creating any robust demarcation 
lines between the two worlds: the spirits merge with the living effortlessly which heightens the sense of unity between them. It is only through a contrast between the light and the darkness, paler facial colouring, ancient costumes or the eerie speech that the director gently alerts the audiences to the presence of the spirits, making the boundaries between visibility and invisibility, presence and absence, extremely fluid and natural. The scene at the annual spirit market (an annual gathering when worlds of the living and the dead are believed to intermingle), for example, shows the living and dead mingling together in a bustling atmosphere typical of a regular market day, making it difficult to distinguish the dead from the living. When Duyên notices her husband sitting at the table with other people, nothing seems to suggest that he is not just another regular man taking a rest from his busy day. Only a close up shot of his paler face exposes him as a ghost. Similarly, in a later scene at the spirit market showing the emotional reunion of Duyên and her husband, we watch them embrace and hold hands, yet a close up shot reveals that their bodies never physically touch. Even though their physical coexistence is no longer possible, their spiritual connection is enduring.

The presence of the ghost in the film is reassuring rather than menacing. No dramatic music or sinister sound effects signal their arrival and the musical score remains soft and lyrical throughout their appearances, invoking a sense of their natural belonging in the world around us. Notwithstanding their not threatening presence, the spirits possess a commanding influence over the living and act as powerful "figures of critique." ${ }^{33}$ The spirits - rather than the state - steer Duyên's recognition of the family's claim on the memory of her husband. When her husband exercises his combined authority as a spirit and as a male by ordering her to rectify her mistake by informing the family of his death, he asserts the supremacy of the kinship over the state.

\section{[INSERT HEALY-FIGURE 4 HERE]}


The cohabitation and social intimacy with ghosts, enacted through ritual acts and votive offerings, is of great significance for the Vietnamese and Đặng Nhật Minh uses a recurring symbol of a paper kite to reinforce this closeness in his film. Before they are married, Duyên's husband makes a kite and they share a carefree afternoon playing with it. Yet soon, the kite assumes a more serious significance, when Duyên's husband decides to burn it in a ritual offering to honour the village spirit. It is a gesture of powerful symbolic importance: on the eve of his medical examination for his military service, when he ceases to be a boy and becomes a soldier, he burns a kite as a votive offering, thus establishing a connection with the past dead warriors enshrined in the figure of the village spirit. The kite, a popular toy of the rural children, is also a symbolic thread that connects the different generations in the family. "Your father was a good kite maker," the grandfather tells his grandson, Tuan, keeping his father's memory alive while at the same time remembering his son. Furthermore, in addition to connecting the past and the present, the kite in this scene poignantly ties together the living and the dead, a fact that remains at this stage in the film's narrative still unknown to Tuan and his grandfather.

The kite features again prominently in the film's finale, soaring high in the sky to evoke new beginnings, hope, and a bright future (it is reasonable to assume that censorship might have influenced this ending). The normal order has been restored and the kite has once again assumed its peaceful meaning as a joyful pastime in the countryside. This final sequence represents one of the scenes where the film seems to be reconciled to a partial restoration of the socialist realist imagery. It is the first day of a new school year and, as Duyên walks with her son to school, life goes on around without any trace of the war; only Duyên's white band of mourning hints at her loss. The close-up shot of Vietnam's national flag surrounded by cheerful children wearing young pioneers' scarfs reinstates the state's authority over the future of Vietnam. Similarly, the character of the soldier who visits the 
dying grandfather reintroduces into the film an idealized state hero - brave and empathic: the soldier is the only person brave and honest enough to disclose the truth, but he is at the same time sensitive enough to help assuage the old man's dying moment by standing in for his deceased son.

Minh's propensity for poetic discourse permeates even those scenes, which are more directly cognizant of the political reality. For example, the ubiquity of the war in the lives of the Vietnamese is alluded to through brief close-up shots of small trivial objects - a child's drawings showing a family with a soldier holding a gun, Tuan's toy gun, the communist flag in front of the school, the school children with their pioneer neck scarfs - these images restore the film's link to the political reality and reintroduce the state's authority over the country's future.

As the film illustrates, embracing the lyrical does not necessitate a detachment from historical reality and a withdrawal from complex social situations. The lyricism helps ignite a more intricate and multi-layered engagement, which penetrates the deeper, personal level, which is necessarily contained within any collective historical action. Through the nurturing of subjectivity, heightened register of emotions, and the lyrical evocation of public and private traditions, the film speaks more emphatically about the war legacy, transcending the specific political milieu to gain a universal relevance. In projecting the lyrical onto history, Minh stimulates a mediatory interaction between politics and aesthetics: the lyrical humanizes the political, thereby paradoxically lending his film a patriotic consciousness so much desired by the official system. Yet his film is provocative rather than compliant: its lyrical ambiguity dispels singular interpretations of the war and validates and honors the suffering of everybody caught in its chaos. 


\section{Conclusion}

As Viet Thanh Nguyen eloquently argues, "all wars are fought twice, the first time on the battlefield, the second time in memory. ${ }^{\prime 34}$ The battlefields of memory are clearly still ablaze as the burgeoning canon of works reinterpreting the Vietnam war(s) testifies. The residues of the Cold War paradigm continue to infringe upon our willingness to comprehend multiple viewpoints and perspectives, which destabilize public memory.

Westadt's assertion that “... US and Soviet interventionisms to a very large extent shaped both the international and the domestic framework within which political, social, and cultural changes in the Third World countries took place" ${ }^{35}$ prompts further investigation into the nature of the specific dynamics within and across individual ideological alliances and in recent years, many scholars have taken up this challenge. The new scholarship exposed a far more elaborate pattern of relations in the international arena during the Cold War than had previously been recognised. Bayly's anthropological research on intellectual endeavour in Vietnam and India, for example, sheds light on the complex cultural connections within the "global socialist ecumene." By stressing that socialism existed in a "broad spectrum of political and cultural modes, ${ }^{, 36}$ she helps to illuminate the intricate deployment of cultural production in a broader system of socialism and shows that socialist cultures were much less isolated, insular, and uniform.

Đặng Nhật Minh became one of the most influential film directors in Vietnam according to Charlot, "an authentic cinema genius," ${ }^{37}$ whose filmmaking is enduringly intertwined with the history of Vietnam. In spite of, or perhaps because of, working in times of upheaval and restricted creative conditions, curtailed not only by ideological demands but also by technical limitations and Spartan working conditions, he created films whose emotional intensity and subdued yet penetrating commentary encapsulate the pressing 
concerns of life in Vietnam and exude his own deep attachment to his country and its people. His haunting and deeply sensual treatment of war loss in When the Tenth Month Comes reflect the difficulty involved in reconciling the past with the present, myths with reality, the private with the collective and the local with the international. In his films, it is not the politics that brings resolution to life's tribulations but humanity, spirituality, nature and timetested traditions. While some of his films touch on politically sensitive issues, labelling them as dissident or privileging their political reading would reawaken the simplistic bipolar perspective of the Cold War era.

Đặng Nhật Minh's work has become important in the process of softening the Cold War polarization, helping to facilitate reconciliation and recognition of the shared humanity between the former enemies. It contributes to the wider contention over representation of Vietnam's past, which has fallen victim to the phenomenal penetration of the Vietnam War into the Hollywood film industry, whose global discursive dominance continues. Through his work, Minh has helped to make the "invisible and absent" Vietnamese reclaim their voice.

\footnotetext{
${ }^{1}$ David Der-Wei Wang, The Lyrical in Epic Time: Modern Chinese Intellectuals and Artists Through the 1949 Crisis (New York: Columbia University Press, 2015), x.

${ }^{2}$ Patricia Pelly, Postcolonial Vietnam: New Histories of the National Past (Durham, NC: Duke University Press, 2002), 113.

${ }^{3}$ Dumont notes that Vietnamese cinema has experienced 'several births'. The French brought film to Vietnam at the end of the $19^{\text {th }}$ century, using it to support their colonial rule. They also offered the local audiences a selection of censored foreign films. Indigenous cinema started in 1924 with an adaptation of Kim Van Kieu. Other films were made in Hong Kong with Vietnamese actors. Between 1954 and 1975 the cinema in South Vietnam developed along separate trajectory than the North Vietnamese cinema - revolutionary film production in the North and commercial film industry in the South.

${ }^{4}$ Marsha Siefert, "Soviet Cinematic Internationalism and Socialist Filmmaking, 1955-72," in Babiracki, Patryk and Austin Jersild (eds.), Socialist Internationalism in the Cold War: Exploring the Second World, (Springer, 2016), 161.

${ }^{5}$ Federico Romero, "Cold War Historiography at the Crossroads," Cold War History, 14:4 (2014): 686.

${ }^{6}$ Heonik Kwon, The Other Cold War (New York: Columbia University Press, 2007), 15.

7 Tony Day and Maya H.T. Liem (eds). Cultures at War: The Cold War and Cultural Expression in Southeast Asia. (Ithaca, NY: Cornell Southeast Asia Program, 2010): 2.
} 
${ }^{8}$ Karl Hack and Geoff Wade, "The Origins of the Southeast Asian Cold War," Journal of Southeast Asian Studies, 40:3 (2009):443.

${ }^{9}$ Giles Scott-Smith and Joes Segal, Introduction: Divided Dreamworlds? The Cultural Cold War in East and West (Amsterdam: Amsterdam University Press, 2012), 2.

${ }^{10}$ Charlot explains the more accommodating attitude of the officials in the Vietnamese film by the fact that the key posts were mostly occupied by film professionals who knew each other rather than by political managers, creating, what Gainsborough calls, "patronage networks," which were often able to mitigate a range of contentious issues without dramatic repercussions. In a similar vein, Kerkvliet notes that state control over culture in Vietnam was never absolute.

${ }^{11}$ Tony Shaw, Cinematic Cold War: The American and Soviet Struggle for Hearts and Minds (Lawrence: University Press of Kansas, 2010), 6.

${ }^{12}$ John Charlot, "Vietnamese Cinema: First Views," Journal of Southeast Asian Studies, 22

(1991): 33-62.

${ }^{13}$ Charlot, Vietnamese Cinema: First Views, 40.

${ }^{14}$ For example, Theo chân ngườ địa chất [In the Footsteps of Geologists, 1968], Hà Bắc quê hương [Hà Bắc- My Native Land, 1969], Tháng năm những gương mặt [The Faces of May, 1975] and Nguyến Trãi [1980].

${ }^{15}$ Lubica Učník, "Aesthetics or Ethics? In Italian Neorealism and the Czechoslovak New Wave Cinema," in Laura E. Ruberto, Kristi M. Wilson, Italian Neorealism and Global Cinema (Detroit: Wayne State University Press, 2007), 55.

${ }^{16}$ Scott, A.O. "New Wave on the Black Sea," The New York Times Magazine, 20 January, 2008.

${ }^{18}$ Mark P. Bradley, "Contests of Memory: Remembering and Forgetting War in the Contemporary Vietnamese Cinema", in Hue-Tam Ho Tai (ed.).The Country of Memory: Remaking the Past in Late Socialist Vietnam (Berkeley: University of California Press, 2001), 198-199.

${ }^{19}$ David Der-Wei Wang, The Lyrical in Epic Time: Modern Chinese Intellectuals and Artists Through the 1949 Crisis, $\mathrm{x}$.

${ }^{20}$ Nguyen Ba Chung, "Between Banks of Truth and Untruth..." in Nguyen Duy, Distant Road (Willimantic: Curbstone Press, 1999), xxiii.

${ }^{21}$ Neil Jamieson, "Shattered Identities and Contested Images: Reflections of Poetry and History in 20th-Century Vietnam," Crossroads: An Interdisciplinary Journal of Southeast Asian Studies, 7:2 (1992).

${ }^{22}$ Eva Näripea, "National Space, (Trans) National Cinema: Estonian Film in the 1960s," in $A$ Companion to East European Cinema (Malden: Wiley, 2012), 249.

${ }^{23}$ Ibid.

${ }^{24}$ Đặng Nhật Minh, Hồi ký điện ảnh [Cinema Diary] (TP Hồ Chí Minh: NXB Vân nghệ, 2005).

${ }^{25}$ Dana Healy, "From Triumph to Tragedy: Visualizing War in Vietnamese Film and Fiction," South East Asia Research 18:2 (2010): 325-47.

${ }^{26}$ Nguyễn Minh Châu, "Writing about War," The Vietnam Review 3 (1997): 435.

${ }^{27}$ In 2008 it was selected as one of the 18 best Asian films of all times by the CNN.

${ }^{28}$ Shaun Kingsley Malarney, "The Fatherland Remembers Your Sacrifice: Commemoration War Dead in North Vietnam," in The Country of Memory: Remaking the Past in Late Socialist Vietnam (Berkeley: University of California Press, 2001), 46-76. 
${ }^{29}$ Mark Bradley, "Contests of Memory: Remembering and Forgetting War in the Contemporary Vietnamese Cinema," in The Country of Memory: Remaking the Past in Late Socialist Vietnam (Berkeley: University of California Press, 2001), 196-226.

${ }^{30}$ John Charlot, Vietnamese Cinema: First Views, 202.

${ }^{31}$ Rosalind Galt, "Italy's Landscapes of Loss: Historical Mourning and the Dialectical Image in 'Cinema Paradiso', 'Mediterraneo' and 'Il Postino'," Screen, 43:2 (2002): 158-173.

${ }^{32}$ Heonik Kwon, Ghosts of War in Vietnam (Cambridge: Cambridge University Press, 2008).

${ }^{33}$ Lan Duong, "Diasporic Returns and the Making of Vietnamese American Ghost Films in Vietnam," MELUS: Multi-Ethnic Literature of the U.S. 41:3 (2016):165.

${ }^{34}$ Viet Thanh Nguyen, Nothing Ever Dies: Vietnam and the Memory of War (Cambridge, Massechusetts, 2016), 4.

${ }^{35}$ Odd Arne Westad, The Global Cold War: Third World Interventions and the Making of Our Times (Cambridge: Cambridge University Press, 2005), 3.

${ }^{36}$ Susan Bayly, Asian Voices in a Post-colonial Age: Vietnam, India and Beyond (Cambridge: Cambridge University Press, 2007), 8.

${ }^{37}$ John Charlot, "Vietnamese Cinema: the Power of the Past," The Journal of American Folklore 102 (1989):447.

\section{Bibliography}

Imre, Anikó. Companion to Eastern European Cinemas. Malden: Wiley, 2012.

Applebaum, R. "The Friendship Project: Socialist Internationalism in the Soviet Union and Czechoslovakia in the 1950s and 1960s". Slavic Review 74:3 (2015): 484-507.

Bayly, Susan. Asian Voices in a Post-colonial Age: Vietnam, India and Beyond. Cambridge: Cambridge University Press, 2007.

Bradley, Mark Philip. "Contests of Memory: Remembering and Forgetting the War in the Contemporary Vietnamese Cinema," In The Country of Memory: Remaking the Past in Late Socialist Vietnam, edited by Hue Tam-Ho Tai, pp. 196-226. Berkeley: University of California Press, 2001.

Charlot, John. "Vietnamese Cinema: the Power of the Past." The Journal of American Folklore 102 (1989):442-452.

Charlot, John. "Vietnamese Cinema: First Views." Journal of Southeast Asian Studies 22 (1991): 33-62.

Đặng Nhật Minh. Bao giơ cho đến tháng mườ: Tuyển tập kịch bản điện ảnh. NXBThuận Hóa. 2002.

Đặng Nhật Minh. Hồi ký điện ảnh [Cinema Diary]. TP Hồ Chí Minh: NXB Vân nghệ. 2005. 
Đặng Nhật Minh. Lời Ai Điếu Cho Một Nền Điện Anh Công Chức. www.talawas.org, 2014.

Day, Tony, and Maya H.T.Liem. Cultures at War: The Cold War and Cultural Expression in Southeast Asia. Ithaca, NY: Cornell Southeast Asia Program, 2010.

De, Cesari, Chiara, and Ann Rigney. Transnational Memory. Circulation, Articulation, Scales. Berlin, Boston: De Gruyter, 2014.

Drummond, Lisa, and Mandy Thomas. Consuming Urban Culture in Contemporary Vietnam. London: Routledge Curzon, 2003.

Dumont, Philippe. "The Multiple Births of Vietnamese Cinema." In Vietnamese Cinema: Le Cinéma Vietnamien, edited by P. Dumont and K. Gormley, pp. 44-60. Lyon: Asiexpo Edition, 2007.

Galt, Rosalind. "Italy's Landscapes of Loss: Historical Mourning and the Dialectical Image in 'Cinema Paradiso', 'Mediterraneo' and 'Il Postino'.” Screen 43:2 (2002):158-173.

Gainsborough, Martin. 'From Patronage to 'Outcomes': Vietnam's Communist Party Congresses Reconsidered.” Journal of Vietnamese Studies 2 (February 2007): 3-26.

Hack, K. and Geoff Wade. "The Origins of the Southeast Asian Cold War." Journal of Southeast Asian Studies 40 (October 2009): 441-448.

Hamilton, Annette. "Renovated: Gender and Cinema in Contemporary Vietnam." Visual Anthropology 22:2-3 (2009): 141-154.

Healy, Dana. "Laments of Warrior's Wives Re-gendering the War in Vietnamese Cinema." Southeast Asia Research 14:2 (2006): 231-259.

Healy, Dana. "From Triumph to Tragedy: Visualizing War in Vietnamese Film and Fiction." South East Asia Research 18: 2 (2010): 325-47.

Herbert, Mark A. Thirty Years After: New Essays on Vietnam War, Literature and Film. Newcastle upon Tyne: Cambridge Scholars Publishing.2009.

Hue-Tam Ho Tai (ed.).The Country of Memory: Remaking the Past in Late Socialist Vietnam. Berkeley: University of California Press, 2001.

Jamieson, Neil. "Shattered Identities and Contested Images: Reflections of Poetry and History in 20th-Century Vietnam." Crossroads: An Interdisciplinary Journal of Southeast Asian Studies 7:2 (1992): 71-134.

B. Kerkvliet, "Authorities and the People: An Analysis of State-Society Relations in Vietnam." In Postwar Vietnam: Dynamics of a Transforming Society, edited by Hy V. Luong, p. 38. Maryland: Rowman \& Littlefield Publishers Inc., 2003. 
Naripea, Eva. "National Space, (Trans)National Cinema: Estonian Film in the 1960s." In $A$ Companion to East European Cinema, edited by A. Imre, pp.244-264. Malden: Wiley, 2012.

Kwon, Heonik. Ghosts of War in Vietnam. Cambridge: Cambridge University Press, 2008.

Kwon, Heonik. The Other Cold War. New York: Columbia University Press, 2010.

Lan Duong. "Spectral Imaginings and National (Be)Longing in When the Tenth Month Comes and Spirits.” Asian Cinema, (Fall/Winter 2007): 5-2.

Lan Duong, "Diasporic Returns and the Making of Vietnamese American Ghost Films in Vietnam.” MELUS: Multi-Ethnic Literature of the U.S. 41 (Fall 2016):152-170.

Marr, David. "A Passion for Modernity: Intellectuals and the Media. In Postwar Vietnam: Dynamics of a Transforming Society, edited by Hy V. Luong. Lanham, MD: Rowman \& Littlefield, 2003.

Marr. David. Mass media in Vietnam. Department of Political and Social Change, Research School of Pacific and Asian Studies, The Australian National University, 1998.

McMahon, Kathryn. "Gender, Paradoxical Space, and Critical Spectatorship in Vietnamese Film: the Works of Dang Nhat Minh." In Trans-status Subjects: Gender in the Globalization of South and Southeast Asia, edited by Sonita Sarker and Niyoki De Esha, pp.108-125. N.C.; London: Duke University Press, 2002.

Marchetti, Gina. "Excess and Understatement: War, Romance, and the Melodrama in Contemporary Vietnamese Cinema." Genders 10 (Spring 1991): 47-74.

Ngô Phương Lan. Modernity and Nationality in Vietnamese Cinema. Yogyakarta: JogjaNETPAC Asian Film Festival, 2007.

Ngô Phương Lan, "The Changing Face of Vietnamese Cinema during Ten Years of Renovation 1986-1996." In The Mass Media in Vietnam, edited by D. Marr, pp. 91-96. Canberra: The Australian National University, 1998.

Pelly, Patricia. Postcolonial Vietnam: New Histories of the National Past. Durham, NC: Duke University Press, 2002.

Romero, Federico Romero. "Cold War Historiography at the Crossroads." Cold War History 14:4, (2014): 685-703.

Romijn, P. Scott-Smith, G. Scott-Smith, and Joes Segal. Divided Dreamworlds? The Cultural Cold War in East and West. Amsterdam: Amsterdam University Press, 2012.

Shaw, Tony and D.J. Youngblood. Cinematic Cold War: The American and Soviet Struggle for Hearts and Minds. Lawrence: University Press of Kansas, 2010. 
Siefert, Marsha. "Soviet Cinematic Internationalism and Socialist Filmmaking, 1955-72." In Socialist Internationalism in the Cold War: Exploring the Second World, edited P. Babiracki, Patryk and Austin Jersild, pp. 161-194. Springer, 2016.

Turner, Karen G. "Shadowboxing with the Censors: A Vietnamese Woman Directs the War Story." In Cinema, Law and the State in Asia, edited by C.K. Creekmuir and M. Sidel, pp. 101-122. New York: Palgrave Macmillan, 2007.

Učník, Lubica. "Aesthetics or Ethics? In Italian Neorealism and the Czechoslovak New Wave Cinema," In Italian Neorealism and Global Cinema, edited by L.E. Ruberto and K.M. Wilson, pp. 54-71. Detroit: Wayne State University Press, 2007.

Viet Thanh Nguyen. Nothing Ever Dies: Vietnam and the Memory of War. Cambridge, Massechusetts: Harvard University Press, 2016.

Westad, Odd Arne. The Global Cold War: Third World Interventions and the Making of Our Times. Cambridge: Cambridge University Press, 2005.

Westrup, L. "Toward a New Canon: The Vietnam Conflict Through Vietnamese Lenses." Film \& History: An Interdisciplinary Journal of Film and Television Studies 36 (Spring 2006): 45-51. 